索引用語: 先天性囊胞状腺腫様奇形, 先天性肺気道奇形, 出生前診断, 縮小 congenital cystic adenomatoid malformation, congenital pulmonary airway malformation, prenatal diagnosis, regression

\section{はじめに}

先天性囊胞状腺腫様奇形 (Congenital cystic adenomatoid malformation : CCAM)/先天性肺気道奇形 (Congenital pulmonary airway malformation：CPAM）は新 生児科領域で遭遇する先天性肺疾患であり，しばしば胎 生期に発見され出生直後に治療されることが多く, 幼少 期以降の発症は比較的稀である。 また, 発生の過程で縮 小，消失する場合があることが知られている．今回我々 は, 胎生期に発見された胸腔内囊胞性病変が出生時には 単純 X 線では指摘されず, 青年期に感染を契機に診断さ れ, 肺葉切除を施行した 1 例を経験したので, 若干の文 献的考察を加えて報告する.

\footnotetext{
*1信州大学医学部附属病院呼吸器外科

*2同 産婦人科

原稿受付 2016年 2 月 9 日

原稿採択 2016年 4 月 12 日

本論文の要旨は第 32 回日本呼吸器外科学会総会にて発表し た
}

\section{症例}

患 者 : 14 歳, 男児.

主 訴: 胸痛.

既往歴：在胎 26 週に胎児エコーで右胸腔内に囊胞性 病変を指摘されたが, 在胎 38 週には同定されなかった (Fig. 1A, B). 出生時, 胎便吸引症候群に対し酸素投与な ど加療を受けた. 生後 5 日目の胸部単純 X 線では右肺野 に異常陰影は指摘されなかった（Fig. 2).

家族歴：特記すべき事項はない.

生活歴: 呼吸器感染症の既往はなく, 学童健診でも異 常を指摘されたことはなかった。中学校の運動部に所属 していた。

現病歴：会話中に突然の右胸痛を自覚したため近医を 受診した．胸部 CT で右肺下葉に液体貯留を伴う大小 様々な囊胞性病変が認められ, 精查目的に当院呼吸器内 科を受診した。吸気時に増悪する胸痛と炎症反応の上昇 が認められ，胸膜炎ならびに囊胞感染を伴う CCAM/ CPAM が疑われた，抗菌薬治療を行い胸痛，炎症反応は 

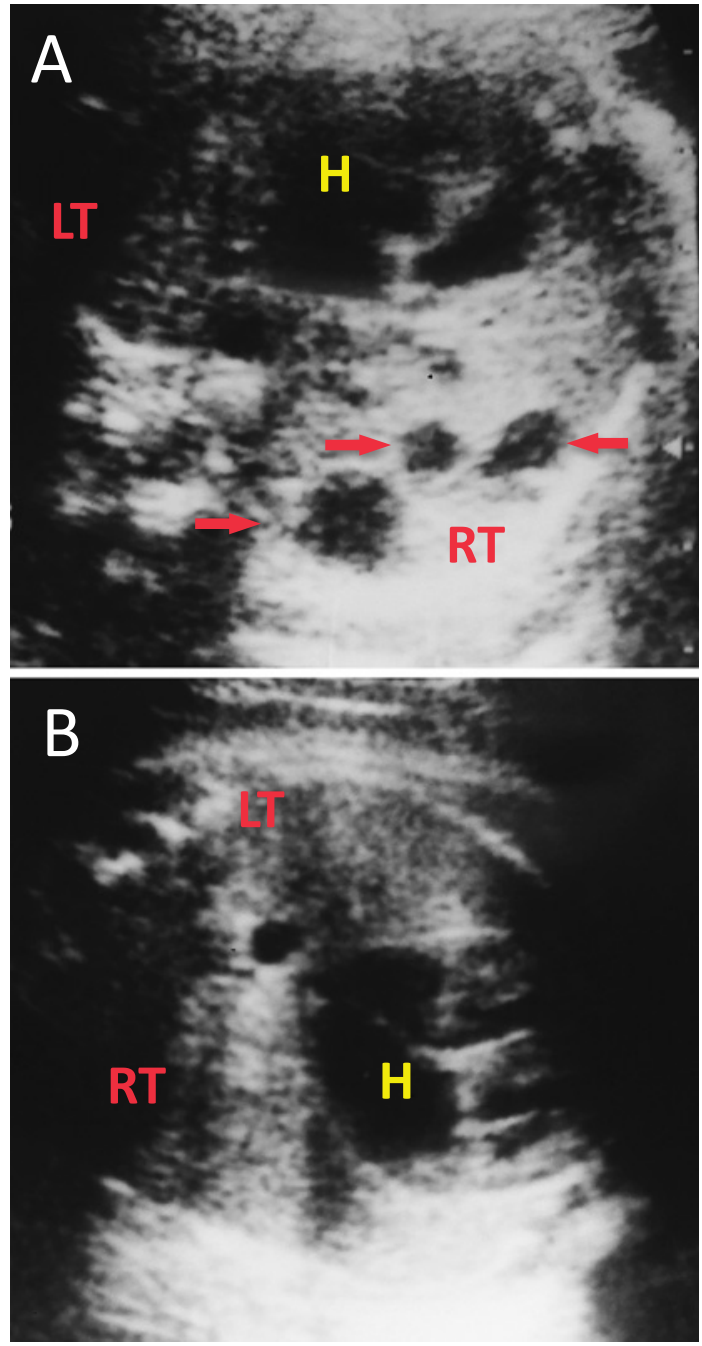

Fig. 1 Prenatal ultrasonography during gestation A. Multiple cysts were seen in the right thorax at 29 weeks (arrow).

B. Cysts in the right thorax were not detected at 38 weeks.

$\mathrm{H}$ heart, RT right thorax, LT left thorax

改善したが, 将来的に感染を繰り返す可能性を考慮し外 科的治療を行う方針となった。

現 症：身長 $165 \mathrm{~cm}$, 体重 $44 \mathrm{~kg}$. 発熱はなく, ラ音は 聴取されなかった。

検査所見 :

血液検査 : WBC 8390, CRP0.16 と炎症反応は陰性で あり, 室内気にて $\mathrm{pO} 2121.0$ と酸素化は良好であった。 そ の他血液検查所見に異常はなかった.

心電図：HR 56 bpm, 正常洞調律.

呼吸機能検査 : FVC 3.43 L, \%FVC 92.2\%, FEV1.0 3.10

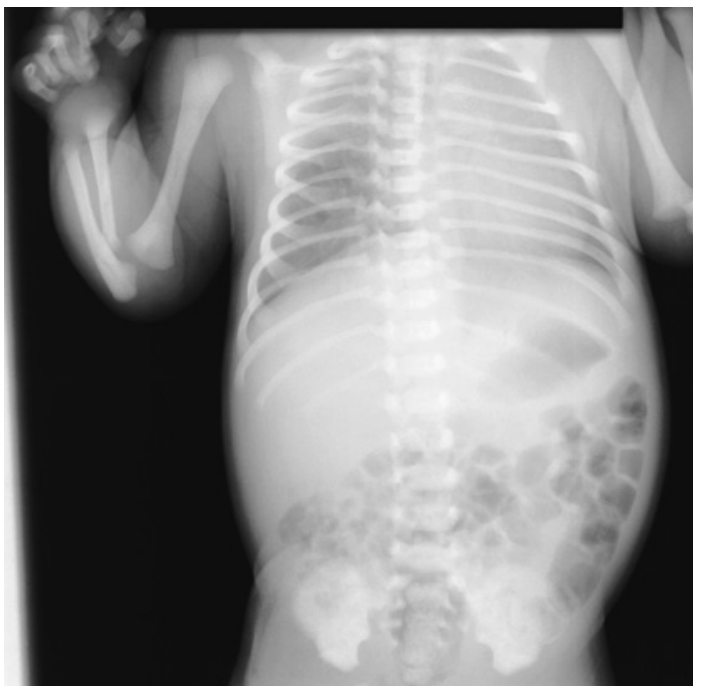

Fig. 2 Chest radiograph at 5 days old did not show the cysts in the right lung field.

L, FEV1.0\% 90.4\%.

画像所見 :

胸部単純 $\mathbf{X}$ 線：右中下肺野に内部に液面形成を伴う 囊胞状陰影が認められた。

胸部 CT（Fig. 3）：右肺下葉に大小不同な多数の囊胞 が認められ, 囊胞壁の肥厚や内部に液体貯留を伴ってい た. 囊胞周囲に浸潤影やスリガラス影が認められ，囊胞 内感染，および周囲への炎症波及を伴う CCAM/CPAM として矛盾しない所見であった。囊胞は右下葉に限局し ており, 病変の形態からは type1 と考えられた.

病変が右下葉全体に及んでいたこと, 呼吸機能は良好 であったことから，胸腔鏡下右下葉切除の方針とした.

手術所見：胸腔内を観察したところ，胸水はなく, S6 に軽度の癒着が認められた。下葉の広範囲に胸膜表面に 凹凸が認められ，内部の囊胞性変化を疑わせた。リンパ 節腫大, 結合織の硬化を認め, 剥離操作に難渋したが, 完全鏡視下に右下葉切除を施行した。手術時間 9 時間 9 分, 出血量 $220 \mathrm{~g}$.

切除標本 : 胸膜面は不整で, 気管支血管束から胸膜下 を含む多くの部分に径数 $\mathrm{mm} \sim 3 \mathrm{~cm}$ 程度までの囊胞性 病変が多発していた。

病理組織所見（Fig. 4)：大小の囊胞性病変が認めら れ, 囊胞壁は線維性に肥厚し線毛円柱上皮で裏打ちされ, 所々で炎症細胞浸潤を伴っていた，膿瘍形成や真菌感染 を示唆する像はなかった。囊胞の大きさから, CCAM/ CPAM type1 と診断された. 

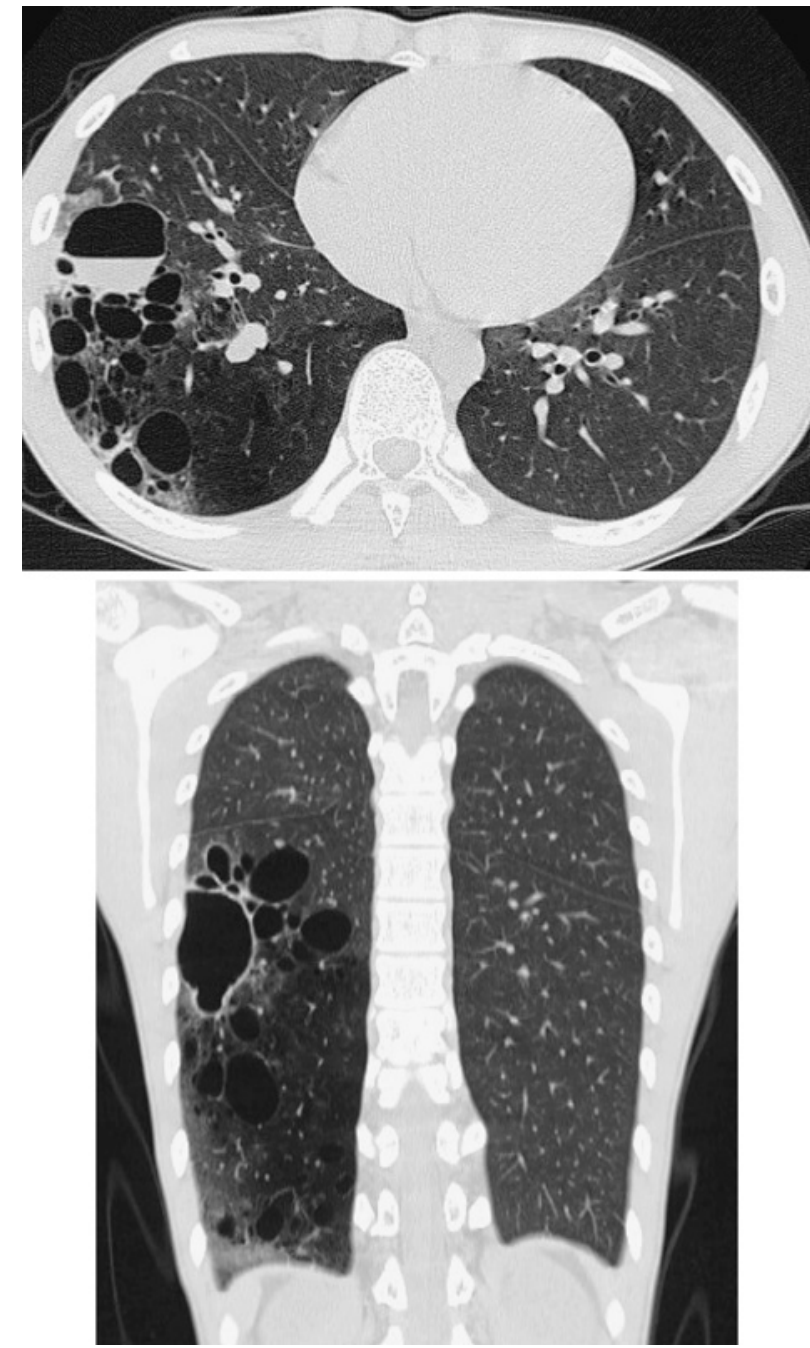

Fig. 3 Chest CT showed a large cyst surrounded by multiple small cysts. All cysts were localized in the right lower lung.

術後経過：肺瘦が遷延したが保存的加療で軽快し，第 9 病日に胸腔ドレーンが抜去され，第 12 病日に退院し た. 術後 2 年経過した現在, 呼吸器感染症の再発はなく, 運動時の呼吸障害も認めてない.

\section{考察}

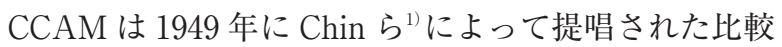
的稀な先天性囊胞性肺疾患群の一つであり分類を Table 1 に示す. Stocker ${ }^{2)}$ により囊胞の大きさをもとに I III 型に分類されたが, その後 0 型, 4 型が追加され, 気管支 から肺胞の各部位と病変の組織像に基づく 5 型に分類さ れた CPAM という名称が提唱された. CCAM/CPAM の組織発生には肺の胎生期の発育異常が関与していると
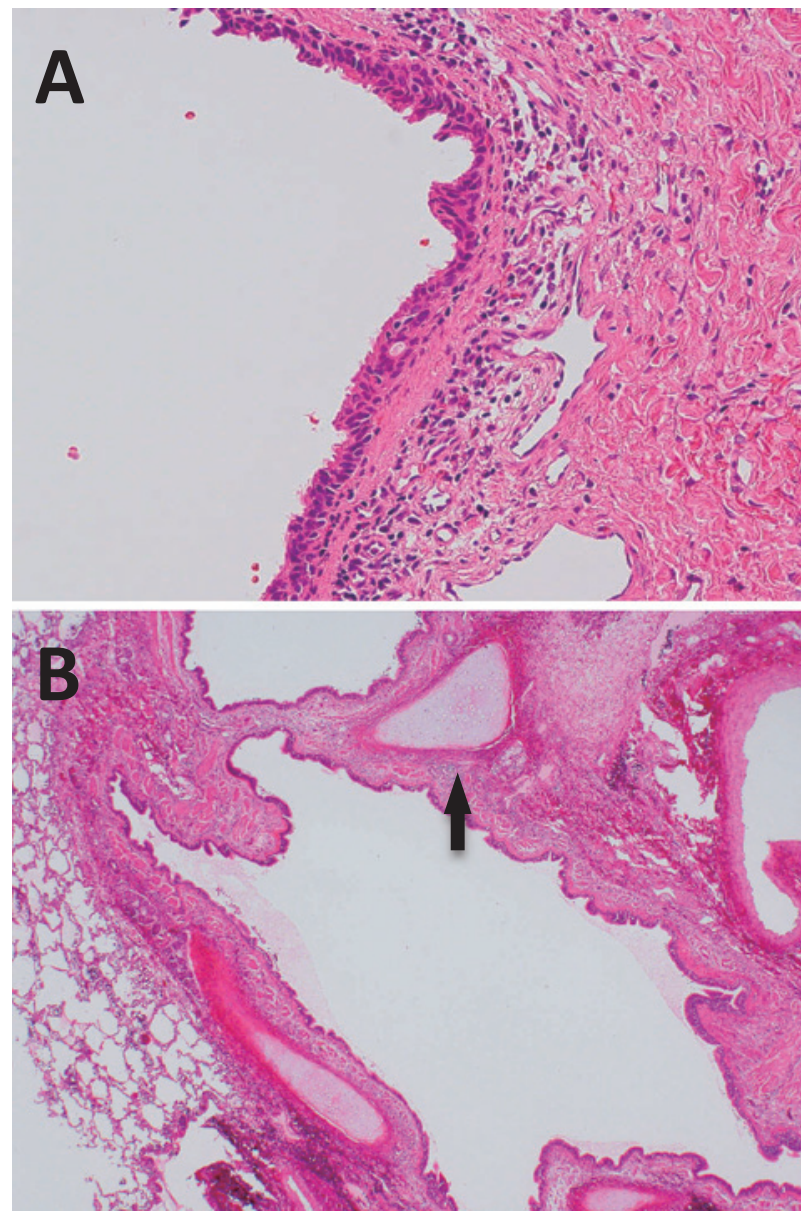

Fig. 4 Microscopic findings revealed multiple cysts covered with ciliated columnar epithelium, accompanied by invasion of inflammation-related cells. Bronchial cartilage was seen (arrow).

(A, H.E. stain, $\times 50$; B, H.E. stain, $\times 2$ ).

考えられており, Morotti ら ${ }^{3)}$ は CPAM 肺と胎生肺の組 織学的比較検討から, CPAM1 3 型は pseudoglandular period（胎生 6〜16 週), CPAM4 型は saccular period に扔ける発生異常と報告している CPAM1 型であり, pseudoglandular period 後の在胎 26 週で異常を指摘された。

CCAM/CPAM は出生後の呼吸開始に伴って囊胞が拡 大し健常肺を圧迫して多呼吸や努力呼吸, チアノーゼな どを来すために大部分が新生览期に発症するが，この時 期には無症状であっても乳児期や学童期に反復性の呼吸 器感染症などにより発見される場合があり, さらに成人 期まで症状がなく, 健診や呼吸器感染症で発見されるこ ともある ${ }^{4,5)} .2000$ 年から 2014 年までに本邦で報告され た CCAM/CPAM の手術例は我々が検索し得た限りで 
Table 1 Pathological features of CCAM/CPAM (cited from articles 2 and 3, partially modified)

\begin{tabular}{cccccc}
\hline CCAM classification & - & I & II & II & - \\
\hline CPAM classification & 0 & 1 & 2 & 3 & 4 \\
\hline Suspected origin & $\begin{array}{c}\text { Trachea/Proximal } \\
\text { bronchus }\end{array}$ & $\begin{array}{c}\text { Bronchus/Proximal } \\
\text { bronchiolus }\end{array}$ & Bronchiolus & $\begin{array}{c}\text { Terminal } \\
\text { bronchiolus/ } \\
\text { alveolar ducts }\end{array}$ & $\begin{array}{c}\text { Distal } \\
\text { acinus }\end{array}$ \\
\hline $\begin{array}{c}\text { Suspected term of } \\
\text { abnormality in fetal period }\end{array}$ & Canalicular & Pseudoglandular & Pseudoglandular & Pseudoglandular & Saccular \\
\hline Epithelial lining & $\begin{array}{c}\text { Ciliated } \\
\text { Peudostratified } \\
\text { Tall columnar } \\
\text { with goblet cells }\end{array}$ & $\begin{array}{c}\text { Pseudiostratified } \\
\text { Tall columnar }\end{array}$ & $\begin{array}{c}\text { Ciliated Cuboidal } \\
\text { or columnar }\end{array}$ & $\begin{array}{c}\text { Ciliated } \\
\text { Cuboidal }\end{array}$ & $\begin{array}{c}\text { Flattened } \\
\text { Alveolar } \\
\text { lining cells }\end{array}$ \\
\hline Mucous cells & + & + & - & - & - \\
\hline Cartilage & + & + & - & - & rare \\
\hline Mucous cells & - & - & + & - & - \\
\hline
\end{tabular}

は 42 例であり，自験例を加えた 43 例を検討した，手術 時年齢は新生児期（生後 1 力月未満） 8 例, 乳児期 $(1$ 力 月 1 歳未満) 12 例, 幼児期 (1 6 歳) 11 例, 学童期 (7〜12 歳) 2 例, 青年期以降 (13 歳〜) は 9 例であった. 幼児期以降の発症例では, 自験例と同様に, 発熱や咳嗽 など, 感染を契機とする症状が主であった。

本疾患に対する治療は, 囊胞病変が大きく出生後に呼 吸不全が存在する場合には可及的速やかに原因病巣の葉 切除を行うのが良いとされている。一方, 囊胞病変が小 さく無症状の場合経過観察される場合もあるが, 病巣肺 が確認されていれば遅くとも概ね 1 歳以下での手術が推 奨されており, これは感染を併発すると炎症が囊胞部位 以外の肺組織に広がり, 胸壁や葉間の癒着が高度になる ことで手術難易度があがることによる ${ }^{6}$. 自験例は, 青年 期まで無症状で経過していたが, 囊胞内感染を伴う胸膜 炎を併発したことで診断され, 速やかに抗菌薬治療を開 始することで他肺葉への炎症の波及を避けることがで き, 難渋したが開胸移行することなく完全鏡視下に肺葉 切除を施行できた．診断時に感染を伴っている場合でも 保存的加療を先行することで, その後の手術治療を比較 的容易にできる可能性が示唆された.

近年の胎児診断技術の進歩により出生前に肺囊胞性疾 患を指摘される機会が増えている . 自験例では, 胎生期 に指摘された胸腔内の囊胞性病変が出生後の胸部 X 線 では確認できず，14歳に至るまで無症状であった，そこ で, CCAM/CAPM の本邦報告 43 例中, 胎生期に胸腔内 に何らかの異常を指摘されていた 15 例を Table $2^{4,6-15)}$ に
示す．自験例以外は全例が新生児期，乳幼児期に手術さ れており，そのうち無症状で手術を行ったものは 6 例, 死亡例は 1 例であった。自験例では, 出生後は短期間の 酸素投与のみで呼吸状態が安定し, 生後の単純 X 線検查 では微小な囊胞を検出できなかった。しかし，生後に肺 炎などの呼吸状態の悪化や CT P MRI 検査などを施行 され囊胞性病変が認められていれば, 新生览期, 乳幼児 期に手術を施行すべきであったと思われる，学童期まで 健康に生活しており学校検診以外の精查は行われておら ず，感染を契機に撮像した CT 検査で初めて多房性の囊 胞性病変を認めたため, 周産期の状況も加味し CCAM/ CPAM と診断することは容易であった.

CCAM/CPAM は診断後には比較的早期に手術治療が 行われるために，長期にわたり経過観察されることがな く, 本疾患の自然史は不明な点が多い. 自験例における 病巣肺は, 発生過程の比較的早期に形成されたことで, 出生までの間に周囲の正常肺が十分に発育する時間的余 裕があり, 出生時には囊胞性病変が圧迫されて縮小し, 出生後も症状がなく経過したのではないかと推測され た. また, Miller $ら^{16)}$ は, 胎生期の正常肺の発育に伴い病 巣肺への血流が減少することも囊胞の縮小に関与した可 能性があるとし，妊娠経過とともに病変が縮小ないしは 消失する症例は予後がよいと報告している，学童期や青 年期の CCAM/CPAM の報告例は，その殆どが胎生期に 異常は指摘されておらず, 生後も精查は受けていない. 胎生期に胸腔内の囊胞性病変を認めた場合は, 生後無症 状であってもその後に呼吸器症状を併発する可能性もあ 





ることを念頭におき, 出生後にCT などの画像評価を行 うことが改めて重要であると考えられた。

\section{結語}

出生時には縮小していた囊胞性病変が青年期になり感 染を併発した CCAM/CPAM の 1 手術例を経験した. 胎 児検査の進歩に伴い胸腔内の囊胞性病変を認めた場合 は, 出生後に CCAM/CPAM を念頭に置いた CT などの 精查をする必要があると思われた.

\section{利益相反}

本論文について申告する利益相反はない.

\section{文献}

1. Chin KY, Tang MY. Congenital adenomatoid malformation of one lobe of a lung with general anasarca. Arch Pathol 1949; 48: 221-9.

2. Stocker JT. Congenital pulmonary airway malformation - a new name for and an expanded classification of congenital cystic adenomatoid malformation of the lung. Histopathology 2002; 41: 424-31.

3. Morotti RA, Cangiarella J, Gutierrez MC, Jagirdar J, Askin F, Singh G, et al. Congenital cystic adenomatoid malformation of the lung (CCAM): evaluation of the cellular components. Hum Pathol 1999; 30: 618-25.

4. 淺部浩史, 岡陽一郎, 白日高歩. 胎児期に異常を指摘され た先天性肺囊胞性疾患の 3 例. 日小外会誌 2006; 42: 8016.

5. 松田佳也, 八柳英治, 草島勝之, 藤井正範, 佐藤啓介. 成 人で発見された Congenital Cystic Adenomatoid Malformation の 1 例. 日呼外会誌 2009; 23: 105-9.

6. 常塚宣男, 清水陽介, 田中伸佳. 1 歳児先天性肺気道奇形 に対する胸腔鏡下肺葉切除術. 胸部外科 2009; 62: 182-6.
7. 八鍬恭子, 五藤亜具里, 長谷川潤一, 横川 香, 大塚純子, 本間 進, 他. 先天性肺謈胞性腺腫様奇形の 1 例. 日産婦 東京会誌 2001; 50: 467-70.

8. 仁尾正記, 神山隆道, 中村 潤, 吉田茂彦, 石井智浩, 和 田 基, 他. 先天性囊胞性腺腫様奇形を合併した乳児肺葉 内肺分画症に対し胸腔鏡補助下分画肺切除術を施行した 1 例. 日小外会誌 2002; 38: 1086-91.

9. 大畠雅之, 永安 武. 先天性囊胞性腺腫様奇形腫を合併し た乳児肺葉内肺分画症の 1 例. 日呼外会誌 2004; 18: 8404 .

10. 湯汲俊悟, 宮内勝敏, 高橋 広, 堀内 淳, 佐藤公一, 河 内寛治. 胎児診断された先天性囊胞性腺腫様奇形の 2 例. 胸部外科 2005; 58: 1098-101.

11. 岩谷さおり, 藤原利男, 土岡 丘, 吉田竜二, 薄井佳子, 砂川正勝. 先天性囊胞性腺様肺奇形 (CCAM) の組織分 類と病態一病態による治療の検討. 小児外科 2006; 38 : 581-7.

12. 岡橋 彩, 牧本優美, 細野茂春, 湊 通嘉, 岡田知雄, 高 橋 滋, 他. CPAM 分類が有用であった congenital pulmonary airway malformation Type 1 の極低出生体重児 例. 日周産期 · 新生览会誌 2009; 45: 899-904.

13. 柴田直昭, 四本由郁, 瀬島 斉, 山口清次. 新生児期に呼 吸障害を来した先天性肺囊胞性疾患の 3 例一画像と病理 所見の検討一. 小児科臨床 2010; 63: 1817-21.

14. 今治玲助, 藤原俊哉, 橋本晋太朗, 佐伯 勇, 秋山卓士. 胎児診断された先天性囊胞性腺腫様肺奇形に対する整容 性に配慮した乳児肺葉切除術. 広島医学 2013; 66: 559-62. 15. 三宅 啓, 福本弘二, 宮野 剛, 矢本真也, 納所 洋, 森 田圭一, 他. 出生直後に緊急ドレナージを施行した I 型 CCAM の 1 例. 日周産期 - 新生児会誌 2014; 50: 129-31.

16. Miller JA, Corteville JE, Langer JC. Congenital cystic adenomatoid malformation in the fetus: natural history and predictors of outcome. J Pediatr Surg 1996; 31: 805-8. 


\title{
A case of congenital cystic adenomatoid malformation in adolescence triggered by infection
}

\author{
Yukihiro Terada ${ }^{* 1}$, Takayuki Shiina*1, Hiroyuki Agatsuma*1 \\ Masayuki Toishi*1, Kenichi Ito* ${ }^{* 1}$, Makoto Kanai ${ }^{* 2}$
}

${ }^{* 1}$ Department of Thoracic Surgery, ${ }^{* 2}$ Department of Obstetrics and Gynecology, Shinshu University School of Medicine

Background. Congenital cystic adenomatoid malformation (CCAM)/ Congenital pulmonary airway malformation (CPAM) is mainly treated in the neonatal period, and so diagnosis after infancy is relatively rare.

Case. A 14-year-old boy was referred to our hospital for the further examination of right chest pain. He had been pointed out as showing a cystic mass in the right thorax prenatally, but the lesion had vanished just before birth. He had not suffered from any pulmonary disorder after birth. Chest CT showed a cavity lesion containing purulent fluid in the right lower lobe. Under a diagnosis of CCAM/CPAM accompanied by pleuritis, he was treated with antibiotics, and right lower lobectomy was performed by VATS. He has not suffered from any respiratory disease for two years since the surgery.

Conclusion. Prenatal CCAM/CPAM sometimes undergoes spontaneous regression, but close investigation should be conducted in order to detect a remaining lesion.

(C) The Japanese Association for Chest Surgery (JACS) 